\title{
Extended spectrum $\beta$-lactamase producing uropathogenic Escherichia coli and the correlation of biofilm with antibiotics resistance in Nepal
}

\author{
Raju Shrestha ${ }^{1^{*}} \mathbb{0}$, Santosh Khanal ${ }^{1}$, Pramod Poudel ${ }^{1}$, Karan Khadayat ${ }^{2}$, Sajani Ghaju ${ }^{2}$, Anita Bhandari ${ }^{3}$, \\ Sunil Lekhak', Narayan Dutt Pant ${ }^{4}$, Manisha Sharma $^{4}$ and Bishnu P. Marasini ${ }^{2}$
}

\begin{abstract}
Background: Urinary tract infection (UTI) is one of the frequently diagnosed infectious diseases which is caused mainly by Escherichia coli. E. coli confers resistance against the two major classes of antibiotics due to the production of extended spectrum $\beta$-lactamase enzymes (ESBL), biofilm, etc. Biofilm produced by uropathogenic E. coli (UPEC) protects from host immune system and prevent entry of antimicrobial compounds. The main objective of this crosssectional study was to determine the correlation of biofilm production and antibiotic resistance as well as to characterize the pgaA and pgaC genes responsible for biofilm formation among uropathogenic ESBL producing E. coli.

Methods: A total of 1977 mid-stream urine samples were examined and cultured for bacterial strain identification. ESBL was detected by combined disc method following CLSI whereas biofilm formation was analyzed by semi-quantitative method. Furthermore, the pgaA and pgaC genes responsible for biofilm formation in UPEC were detected by multiplex PCR. All the statistical analyses were done via IBM SPSS Statistics 21 where Pearson's correlation test were used to determine correlation $(-1 \geq r \leq 1)$.

Results: E. coli was the predominant causative agent, which accounted 159 (59.3\%) of the Gram-negative bacteria, where 81 (50.9\%) E. coli strains were found to be ESBL producers. In addition, 86 (54.1\%) E. coli strains were found to be biofilm producers. Both the pgaA and pgaC genes were detected in 45 (93.7\%) the UPEC isolates, which were both biofilm and ESBL producers. Moreover, there was a positive correlation between biofilm and ESBL production.

Conclusion: The analyses presented weak positive correlation between biofilm and ESBL production in which biofilm producing UPEC harbors both pgaA and pgaC genes responsible for biofilm formation.
\end{abstract}

Keywords: E. coli, UTI, ESBL, Biofilm, pgaA and pgaC

\section{Background}

Over 150 million new cases of urinary tract infection (UTI) are diagnosed worldwidely per year $[1,2]$, therefore, UTI is one of the health complications that need a serious concern [3]. Escherichia coli are the main

\footnotetext{
*Correspondence: shrestharaj167@gmail.com

${ }^{1}$ Department of Microbiology, National College, Tribhuvan University, Naya Bazar, Kathmandu, Nepal

Full list of author information is available at the end of the article
}

causative agent of UTI fulminating prostatitis, biliary tract infection, and urinary catheter cystitis [4] which accounts approximately 80 to $85 \%$ of the cases [5-7]. Biofilm (poly- $\beta-1,6-N$-acteyl-D-glucosamine i.e., PGA) production is one of the arsenals of $E$. coli to invade the host. The pgaABCD locus of $E$. coli is required for synthesis of biofilm and other pathogenic role [4, 17]. The biofilm formation via pgaABCD depends on various factors viz. fimbriae, type I pili, motility, etc. This class of 
polysaccharides in E. coli was recently discovered and acts as an adhesive in biofilms [4]. Biofilms help not only in the transfer of plasmid encoding resistance genes i.e., ESBL to other organisms via conjugation but also resist immune clearance [9-13]. The dissemination of ESBLs has emerged to a high proportion of CTX-M enzymes, notably $E$. coli, which is the major carriers of ESBLencoding genes i.e. bla $_{\mathrm{CTX}-\mathrm{M}}[11,14,15]$ so, the incidence of ESBL producing $E$. coli is now elevating in urinary tract infections [16].

The uropathogenic E. coli is now developing new trends of antimicrobial resistance as well as their biofilm is supporting to gain the resistance against numerous antibiotics $[6,8,13]$. To our knowledge, this study would be first in Nepal to determine the correlation of biofilm formation and antibiotic resistance as well as to characterize the biofilm producing genes located in $p g a A B C D$ locus among uropathogenic ESBL producing E. coli.

\section{Methods}

The cross-sectional study was carried out in the Department of Microbiology, Grande International Hospital, Tokha, Kathmandu, and Department of Microbiology, National College, Kathmandu from June to November, 2017. A clinical and socio-demographic study of patients was performed. A total of 1977 mid-stream urine were cultured semi-quantitatively on Cysteine Lactose Electrolyte Deficient Agar plates and incubated at $37{ }^{\circ} \mathrm{C}$ for $24 \mathrm{~h}[6,18,19]$. The antibiotic susceptibility test was performed by modified Kirby-Bauer method of disk diffusion within the guidelines of Clinical and Laboratory Standard Institute (CLSI), 2015 [18-20].

\section{Detection of ESBL producing uropathogenic $E$. coli}

The resistance of cefotaxime $(30 \mu \mathrm{g})$ in E. coli was used as the screening method for detection of ESBL which were then confirmed by combined disc method following CLSI, 2015 [20].

\section{Detection of biofilm production in E. coli}

The uropathogenic E.coli were cultured in $5 \mathrm{ml}$ of LuriaBertani (LB) broth at $37^{\circ} \mathrm{C}$ for $24 \mathrm{~h}$. The turbidity of cultured LB broth was compared with the 0.5 McFarland standard to maintain $10^{8} \mathrm{CFU} / \mathrm{ml}$ followed by addition of LB broth supplemented with $1 \%$ glucose in the ratio 1:100 to maintain the concentration of approximately $10^{6} \mathrm{CFU} /$ $\mathrm{ml}$. It was then vortexed and $200 \mu \mathrm{l}$ of diluted cultured LB broth was transferred per well in a microtiter plate in triplicate. A positive control i.e. $200 \mu \mathrm{l}$ of $E$. coli ATCC 25922 cultured LB broth and a negative control i.e. $200 \mu \mathrm{l}$ of LB broth were transferred into well of a microtiter plate in triplicate. The microtiter plates were covered with a tape and incubated at $37{ }^{\circ} \mathrm{C}$ for overnight. The plates were washed 3 times with $300 \mu \mathrm{l}$ of sterile phosphate buffered saline (PBS, pH 7.2). Subsequently, plates were heat fixed by incubating at $60{ }^{\circ} \mathrm{C}$ for $1 \mathrm{~h}$. Then, the plates were stained with $150 \mu \mathrm{l}$ of $2 \%$ crystal violet for $15 \mathrm{~min}$ at room temperature. The plates were washed with distilled water until the stain was free. It was then air dried at room temperature. Afterward, $150 \mu \mathrm{l}$ of $95 \%$ ethanol (v/v) was transferred per well in microtiter plates. The covered microtiter plates were left at room temperature for half an hour without shaking. The absorbance was measured at $570 \mathrm{~nm}$ using a spectrophotometer. The uropathogenic $E$. coli was classified as a non-biofilm producer, weak biofilm producer, moderate biofilm producer, or strong biofilm producer on the basis of findings evaluated $[21,22]$.

\section{Detection of biofilm genes i.e. pgaA and pgaC in E. coli}

The genomic DNA was extracted from the ESBL and biofilm producing uropathogenic $E$. coli via a standard phenol-chloroform protocol [23]. Multiplex PCR was done to detect $p g a A$ and $p g a C$ genes in which the $p g a A$ and $p g a C$ primers were used for the amplification of 209 and $540 \mathrm{bp}$, respectively (Table 1) [24, 25].

At first, $12.5 \mu \mathrm{l}$ of Master Mix (Biolabs, New England) was added followed by $8.5 \mu \mathrm{l}$ nuclease-free water, $0.5 \mu \mathrm{l}$ of each primer (Macrogen, Inc., South Korea) of both genes and $2 \mu \mathrm{l}$ of DNA from the bacterial strains to maintain $25 \mu \mathrm{l}$ PCR mixture (TAKARA PCR Thermal Cycler Dice Gradient TP600, Takara bio, Tokyo, Japan). PCR conditions i.e., initial 5 min denaturation step at $94{ }^{\circ} \mathrm{C}$ was maintained followed by 32 cycles of $30 \mathrm{~s}$ at $94{ }^{\circ} \mathrm{C}, 30 \mathrm{~s}$ at $50{ }^{\circ} \mathrm{C}$, and $45 \mathrm{~s}$ at $72{ }^{\circ} \mathrm{C}$, and a final extension step of $5 \mathrm{~min}$ at $72{ }^{\circ} \mathrm{C}$ [24].

\section{Data analysis}

All the data collected were analyzed via IBM SPSS Statistics 21. Pearson's correlation test were used to determine correlation $(-1 \geq r \leq 1)[1,6]$.

\section{Results}

Among 1977 mid-stream urine samples, a total of 311 $(15.7 \%)$ isolates were isolated with significant growth i.e., $\geq 10^{5} \mathrm{cfu} / \mathrm{ml}$ where $159(51.1 \%) E$. coli strains were isolated. Out of 159 E. coli strains, 81 (50.9\%) were ESBL

Table 1 The forward and reverse primers used in pgaA and pgaC genes

\begin{tabular}{lllll}
\hline Gene & Primers & Sequences & GC \% & Tm $\left({ }^{\circ} \mathbf{C}\right)$ \\
\hline pgaA & Forward & 5'-GGCTTTGAAACTTCTTACTGC-3' & 42.9 & 57.4 \\
& Reverse & 5'-CCTGTTTATCTTGCCCGGCC-3' & 60 & 62.5 \\
pgaC & Forward & 5'-ATGATTAATCGCATCGTATCG-3' & 38.1 & 55.5 \\
& Reverse & 5'-CATCGGTTCCACAATATATGC-3' & 42.9 & 57.4 \\
\hline
\end{tabular}


Table 2 Clinical and socio-demographic study

\begin{tabular}{lll}
\hline S. No. & Status of patient & Number (\%) \\
\hline 1 & In-patient & $93(29.9 \%)$ \\
2 & Out-patient & $218(70.1 \%)$ \\
\hline S. No. & Gender & Number (\%) \\
\hline 1 & Male & $138(44.7 \%)$ \\
2 & Female & $173(55.3 \%)$ \\
\hline S. No. & Age distribution & Number (\%) \\
\hline 1 & $0-20$ & $28(9 \%)$ \\
2 & $20-40$ & $99(31.83 \%)$ \\
3 & $40-60$ & $91(29.26 \%)$ \\
4 & $60+$ & $93(29.91 \%)$ \\
\hline
\end{tabular}

Table 3 Antibiotic susceptibility profile of uropathogenic E. coli isolates

\begin{tabular}{lccll}
\hline $\begin{array}{l}\text { Antibiotic } \\
\text { used }\end{array}$ & Sensitive & Intermediate & Resistance & Total isolates \\
\hline Amoxyclav & $65(40.9 \%)$ & $12(7.5 \%)$ & $82(51.6 \%)$ & 159 \\
Cefotaxime & $69(43.4 \%)$ & $8(5 \%)$ & $82(51.6 \%)$ & 159 \\
Colistin & $140(88.1 \%)$ & $0(0 \%)$ & $19(11.9 \%)$ & 159 \\
Cotrimoxa- & $69(43.4 \%)$ & $0(0 \%)$ & $90(56.6 \%)$ & 159 \\
zole & & & & \\
Gentamycin & $124(78 \%)$ & $9(5.7 \%)$ & $26(16.4 \%)$ & 159 \\
Meropenem & $121(76.1 \%)$ & $24(15.1 \%)$ & $14(8.8 \%)$ & 159 \\
Nitrofuran- & $135(84.9 \%)$ & $14(8.8 \%)$ & $10(6.3 \%)$ & 159 \\
toin & & & & 159 \\
Norfloxacin & $52(32.7 \%)$ & $8(5 \%)$ & $99(62.3 \%)$ & 159 \\
Tigecycline & $159(100 \%)$ & $0(0 \%)$ & $0(0 \%)$ & 159 \\
\hline
\end{tabular}

producer, 86 (54.1\%) were biofilm producer in which 48 (30.2\%) were both ESBL and biofilm producer. Within 48 $E$. coli strains, which were both ESBL and biofilm producer, 45 (93.7\%) strains showed both $p g a A$ and $p g a C$ genes that are responsible for biofilm production.

\section{Clinical and socio-demographic study}

Community-acquired infections was found to be higher which accounts $218(70.1 \%)$ and female were affected by 173 (55.3\%). Moreover, the higher number of cases was observed within the age group $60+$ which accounts 93 (29.91\%) (Table 2).

\section{Antibiotics susceptibility profile}

Out of 159 E. coli strains, $82(51.6 \%)$ and 90 (56.6\%) were resistant towards to cefotaxime and cotrimoxazole, respectively whereas $159(100 \%)$ E. coli strains were sensitive towards tigecycline (Table 3 ).

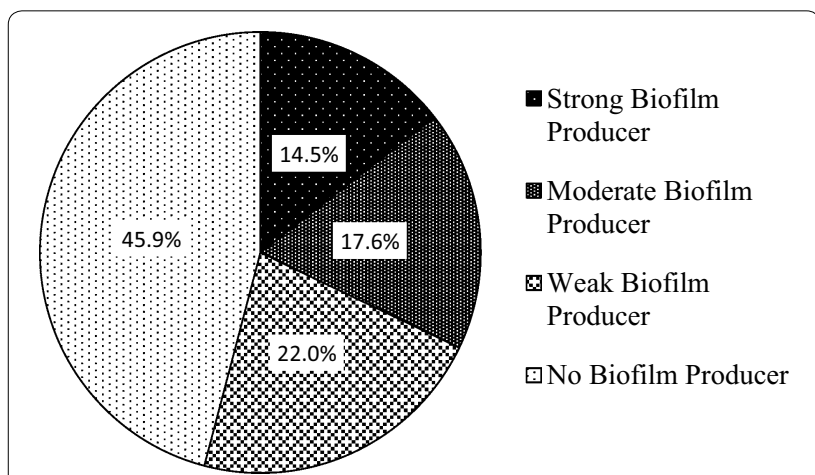

Fig. 1 Detection of biofilm production in uropathogenic E. coli via semi-quantitative method

Detection of biofilm formation by the semi-quantitative method

Out of 159 (51.1\%) UPEC, 23 (14.5\%) strains were found to be strong biofilm producer, $28(17.6 \%)$ strains were moderate biofilm producer and $35(22 \%)$ strains were weak biofilm producer whereas $73(45.9 \%)$ strains were found to be biofilm non-producer (Fig. 1).

\section{Correlation between biofilm production}

by the semi-quantitative method and ESBL production in E. coli.

Amongst ESBL producing UPEC, 18.5\%, 17.3\%, and $23.5 \%$ showed strong, moderate and weak production of biofilm, respectively. There was a weak positive correlation between biofilm formation and ESBL production $(r=0.157)$ which is illustrated in Table 4 .

\section{Detection of biofilm genes i.e., pgaA and pgaC in E. coli}

Among 48 uropathogenic $E$. coli processed which were ESBL and biofilm producers, 14 (93.3\%) strong, 14 (100\%) moderate and 17 (89.5\%) weak biofilm producing and ESBL producing UPEC were found to contain both pgaA and pgaC genes which is amplified at $209 \mathrm{bp}$ and 540 bp, respectively (Fig. 2). E. coli ATCC 25922 was used as a positive control for pgagenes (Table 5).

\section{Discussion}

Urinary tract infections are frequently occurred infections in hospital where 93 (29.9\%) were hospital acquired infections. The prevalence rate of urinary tract infections in female was found to be predominant $(55.3 \%)$ than male (44.7\%) because of the close proximity between vagina and anus [1], cystitis, sexual behavior, vaginal infections, pregnancy, diabetes mellitus, obesity and genetic sensitivity in female $[2,36]$. In addition, the prevalence rate of infection was found to be higher in age groups $60+$ years. 
Table 4 Correlation between biofilm and ESBL production in E. coli

\begin{tabular}{|c|c|c|c|c|c|c|}
\hline ESBL detection & $\begin{array}{l}\text { Strong biofilm } \\
\text { producer }\end{array}$ & $\begin{array}{l}\text { Moderate biofilm } \\
\text { producer }\end{array}$ & $\begin{array}{l}\text { Weak biofilm } \\
\text { producer }\end{array}$ & No biofilm producer & Total isolates & $R$-value \\
\hline ESBL Producer & $15(18.5 \%)$ & $14(17.3 \%)$ & $19(23.5 \%)$ & $33(40.7 \%)$ & $81(50.9 \%)$ & 0.157 \\
\hline ESBL non-producer & $8(10.3 \%)$ & $14(17.9 \%)$ & $16(20.5 \%)$ & $40(51.3 \%)$ & 78 (49.1\%) & \\
\hline Total & $23(14.5 \%)$ & $28(17.6 \%)$ & $35(22 \%)$ & 73 (45.9\%) & 159 (100\%) & \\
\hline
\end{tabular}

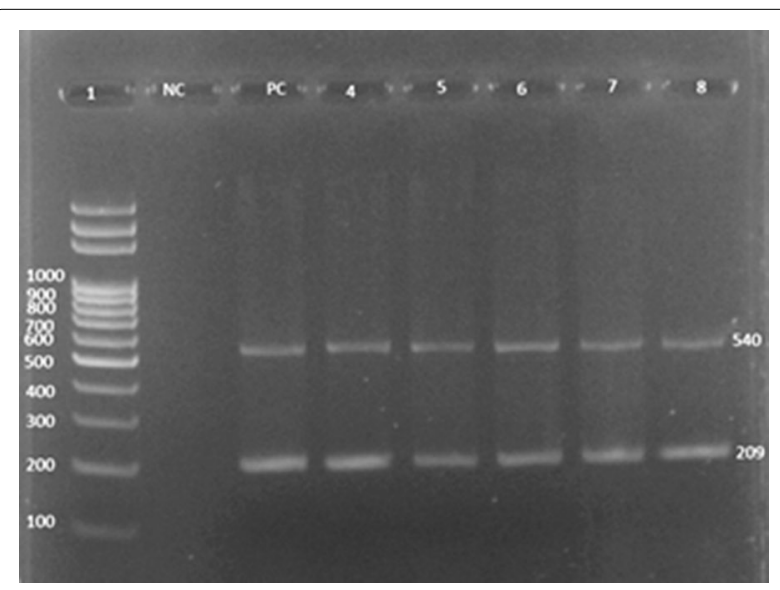

Fig. 2 The $p g a A$ and pgaCgenes detection in E. coli strains: lane 1 is the DNA ladder labeling from 100 to $1000 \mathrm{bp}, \mathrm{NC}$ and PC are negative and positive controls, respectively; lanes 4, 5, 6, 7 and 8 are positive for both the pgaA and pgaCgenes at $209 \mathrm{bp}$ and $540 \mathrm{bp}$, respectively

Table 5 Detection of pgaA and pgaC genes by multiplex PCR

\begin{tabular}{llll}
\hline Sample & \multicolumn{2}{l}{$\begin{array}{l}\text { Detection of } p g a A \text { and pgaC } \\
\text { genes }\end{array}$} & Total \\
\cline { 2 - 3 } & Positive & Negative & \\
\hline Strong biofilm producer & $14(93.3 \%)$ & $1(6.7 \%)$ & 15 \\
Moderate biofilm producer & $14(100 \%)$ & 0 & 14 \\
Weak biofilm producer & $17(89.5 \%)$ & $2(89.5 \%)$ & 19 \\
Total & $45(93.7 \%)$ & $3(6.3 \%)$ & 48 \\
\hline
\end{tabular}

From the above evidences, it was clear that urinary tract infections were found to be more prone to older ages rather than younger ages. It is due to the fact that with the ageing, immune response tends to decline gradually and also hormonal changes takes place which leads to infections of urinary tract [36].

E. coli was found to be a predominant causative agent of UTI which was highly resistant towards norfloxacin 99 (62.3\%), cotrimoxazole 90 (56.6\%) and cefotaxime $82(51.6 \%)$ and their resistance patterns were found to be similar with the earlier study conducted $[8,10,11]$.
There was a weak positive correlation $(r=0.157)$ relationship between biofilm production and ESBL productions. Within strong, moderate and weak biofilm producing $E$. coli, $65.2 \%, 50 \%$ and $54.3 \%$ were ESBL producer, respectively. There was positive correlation between biofilm and ESBL producing $E$. coli which was stated by Tabasi et al. and Neupane et al. $[6,8]$. This revealed that biofilm favors the ESBL gene transferred between the E. coli and other microorganisms because of matrix which stabilizes and enhances the transferability of genetic elements horizontally as well as resist the immune clearance [6, 21, 30-32].

The $p g a A B C D$ locus is selected to detect the $p g a A$ and pgaC genes by multiplex PCR as it contributes in production of $\beta-1,6-N$-acetyl-D-glucosamine, surface adherence as well as intracellular adhesion [24, 25]. The protein, $\mathrm{PgaC}$ is responsible for production of $\beta-1,6-N$-acetyl-Dglucosamine as it utilizes UDP- $N$-acetyl glucosamine as a substrate, and PgaA helps in translocation and anchoring of $\beta-1,6-N$-acetyl-D-glucosamine to cell surfaces [4]. The $p g a A$ and $p g a C$ genes were found to harbor in 45 (93.7\%) out of 48 biofilm as well as ESBL producing UPEC. Nonetheless, $p g a$ locus was found to be absent in $3(6.3 \%)$ biofilm as well as ESBL producing UPEC. It may be due to involvement of variety of genes, i.e. $\mathrm{crl}, \mathrm{csg}, \mathrm{cvaC}$, fimA, fimH, iutA, ompC, ompF, sfaS, traT, yidC, etc. responsible for the production of biofilm [24, 34, 35].

The development of resistance in E. coli may be due to haphazard use of antibiotics, plasmid-mediated genes, i.e. $b l a_{\mathrm{CTX}-\mathrm{M}}, b l a_{\mathrm{SHV}}, b l a_{\mathrm{OXA}}$, etc., quorum sensing, etc. [26-29]. The rise of multidrug-resistant UPEC poses a serious threat to manage UTI along with increment in treatment cost. The biofilm producing pathogens are sensitive towards co-therapy with macrolides i.e. erythromycin, clarithromycin and azithromycin, and other effective antibiotics as macrolides are considered as reliable antibiofilm agents $[6,33]$.

\section{Conclusion}

In conclusion, tigecycline were found to be pragmatic approach for treatment as the result indicates in this research. There was found to be weak positive correlation between biofilm and ESBL production. In addition, 
biofilm producing UPEC harbors both $p g a A$ and $p g a C$ genes responsible for biofilm production.

\section{Limitations of study}

The study of all genes responsible for biofilm production other than pgaA and $p g a C$ genes and the genes ESBL productions could not be carried out. Genes like mcr-1 and NDM-1 for colistin and meropenem resistant strains were not performed respectively to confirm the resistivity.

\section{Abbreviations}

CLSI: Clinical and Laboratory Standards Institute; UPEC: uropathogenic E. coli.

\section{Acknowledgements}

We would like to thank Mrs. Sarita Manandhar for guidance and Grande International Hospital and National College, Kathmandu, Nepal for providing the laboratories to carry out this study.

\section{Authors' contributions}

RS was the principal investigator who was responsible for conceptualizing study, research design, sample collection, processing and analyzing data as well as writing manuscript. KK, SG and AB were responsible for sample collection, processing and analyzing data. SK, PP, SL, NDP, MS and BPM were responsible for conceptualizing study, designing research and writing manuscript. All authors read and approved the final manuscript.

\section{Funding}

There was no funding organization for this paper.

\section{Availability of data and materials}

Data sharing is not applicable to this paper as the datasets generated needed to be confidential.

\section{Ethics approval and consent to participate}

The ethical clearance and consent to participate was approved by Nepal Health Research Council.

\section{Consent for publication}

Not applicable.

\section{Competing interests}

The authors declare that they have no competing interests.

\begin{abstract}
Author details
${ }^{1}$ Department of Microbiology, National College, Tribhuvan University, Naya Bazar, Kathmandu, Nepal. ${ }^{2}$ Department of Biotechnology, National College, Tribhuvan University, Naya Bazar, Kathmandu, Nepal. ${ }^{3}$ Department of Microbiology, Goldengate International College, Tribhuvan University, Kathmandu, Nepal. ${ }^{4}$ Department of Microbiology, Grande International Hospital, Kathmandu, Nepal.
\end{abstract}

Received: 16 September 2019 Accepted: 1 December 2019

Published online: 17 December 2019

\section{References}

1. McLellan LK, Hunstad DA. Urinary tract infection: pathogenesis and outlook. Trends Mol Med. 2006;22:946-57.

2. Flores-Mireles AL, Walker JN, Caparon M, Hultgren SJ. Urinary tract infections: epidemiology, mechanisms of infection and treatment options. Nat Rev Microbiol. 2015;13:269-84.

3. Harwalkar A, Sataraddi J, Gupta S, Yoganand R, Rao A, Srinivasa H. The detection of ESBL-producing Escherichia coli in patients with symptomatic urinary tract infections using different diffusion methods in a rural setting. J Infect Public Health. 2013;6:108-14.

4. Wang X, lii JFP, Romeo T. The pgaABCD locus of Escherichia coli promotes the synthesis polysaccharide adhesin required for biofilm formation. J Bacterio ASM. 2004;186:2724-34.

5. Lepeule R, Leflon-Guibout V, Vanjak D, Zahar JR, Lafaurie M, Besson C, Therby A. Clinical spectrum of urine cultures positive for ESBL-producing Escherichia coli in hospitalized patients and impact on antibiotic use. Med Mal Infect. 2014:44:530-4.

6. Neupane S, Pant ND, Khatiwada S, Chaudhary R, Banjara MR. Correlation between biofilm formation and resistance toward different commonly used antibiotics along with extended spectrum beta lactamase production in uropathogenic Escherichia coli isolated from the patients suspected of urinary tract infections visit. Antimicrob Resist Infect Control. 2016;5:5

7. Paterson DL. Medically important members of the infections due to other members of the Enterobacteriaceae, multidrug-resistant strains. Goldman's Cecil Medicine. 2012;24/e:1874-7.

8. Tabasi M, Asadi Karam MR, Habibi M, Yekaninejad MS, Bouzari S. Phenotypic assays to determine virulence factors of uropathogenic Escherichia coli (UPEC) isolates and their correlation with antibiotic resistance pattern. Osong Public Health Res Perspect. 2015;6:261-8.

9. Donlan RM. Biofilms: microbial life on surfaces. Emerg Infect Dis. 2002;8:881-90.

10. Al-Assil B, Mahfoud M, Hamzeh AR. Resistance trends and risk factors of extended spectrum $\beta$-lactamases in Escherichia coli infections in Aleppo, Syria. Am J Infect Control. 2013;41:597-600.

11. El Bouamri MC, Arsalane L, Zerouali K, Katfy K, El kamouni Y, Zouhair S. Molecular characterization of extended spectrum $\beta$-lactamaseproducing Escherichia coli in a university hospital in Morocco, North Africa. Afr J Urol. 2015:21:161-6.

12. Wragg R, Harris A, Patel M, Robb A, Chandran H, McCarthy L. Extended spectrum beta lactamase (ESBL) producing bacteria urinary tract infections and complex pediatric urology. J Pediatr Surg. 2017;52:286-8.

13. Ponnusamy P, Natarajan V, Sevanan M. In vitro biofilm formation by uropathogenic Escherichia coli and their antimicrobial susceptibility pattern. Asian Pac J Trop Med. 2012;5:210-3.

14. Pitout JD, Laupland KB. Extended-spectrum $\beta$-lactamase-producing Enterobacteriaceae: an emerging public-health concern. Lancet Infect Dis. 2008;8:159-66.

15. Rodríguez-baño J, Navarro MD, Martínez-martínez L, Muniain MA, Perea J, Pérez-cano R, Perea EJ. Epidemiology and clinical features of infections caused by extended-spectrum beta-lactamase-producing Escherichia coli in nonhospitalized patients. J Clin Microbiol. 2004;42:1089-94.

16. Ghafourian S, Sadeghifard N, Soheili S, Sekawi Z. Extended spectrum beta-lactamases: definition, classification and epidemiology. Curr Issues Mol Biol. 2015;17(1):11-22.

17. Itoh Y, Rice JD, Goller C, Pannuri A, Taylor J, Meisner J, Romeo T. Roles of pgaABCD genes in synthesis, modification, and export of the Escherichic coli biofilm adhesin poly- $\beta-1,6-\mathrm{N}$-acetyl-D-glucosamine. J Bacteriol. 2008;190:3670-80.

18. Cheesbrough M. District laboratory practice in tropical countries Part 2. 2nd ed. USA: Cambridge University Press; 2016. p. 105-14.

19. Winn W, Allen S, Janda W, Konemon E, Procop G, Schreckenberger P, Woods G. Koneman's color atlas and textbook of diagnostic microbiology. 6th ed. New York: Lippincott Williams and Wilkins; 2005. p. 228-77.

20. Clinical and Laboratory Standards Institute (CLSI). Performance standards for antimicrobial susceptibility testing: twenty-fifth informational supplement [S]. CLSI document M100-S25. 2015, Wayne: Clinical and Laboratory Standards Institute.

21. Maheshwari M, Ahmad I, Althubiani AS. Multidrug resistance and transferability of blaCTX-M among extended-spectrum $\beta$-lactamase-producing enteric bacteria in biofilm. J Glob Antimicrob Resist. 2016;6:142-9.

22. Salimena APS, Lange CC, Camussone C, Signorini M, Calvinho LF, Brito MAVP, Piccoli RH. Genotypic and phenotypic detection of capsular polysaccharide and biofilm formation in Staphylococcus aureus isolated from bovine milk collected from Brazilian dairy farms. Vet Res commun. 2016:40:97-106.

23. Sambrook J, Russell DW. Molecular cloning: a laboratory manual. Cold Spring Harbor: Cold Spring Harbor Laboratory Press; 2001. p. 19-94. 
24. Cerca N, Maira-Litrán T, Jefferson KK, Grout M, Goldmann DA, Pier GB. Protection against Escherichia coli infection by antibody to the Staphylococcus aureus poly-N-acetylglucosamine surface polysaccharide. Proc Natl Acad Sci. 2007;104:7528-33.

25. Cremet L, Corvec S, Batard E, Auger M, Lopez I, Pagniez F, Caroff N. Comparison of three methods to study biofilm formation by clinical strains of Escherichia coli. Diagn Microbiol Infect Dis. 2013;75:252-5.

26. Delgado-Valverde M, Sojo-Dorado J, Pascual Á, Rodríguez-Baño J. Clinical management of infections caused by multidrug-resistant Enterobacteriaceae. Ther Adv Infect Dis. 2013;1:49-69.

27. Oztürk H, Ozkirimli E, Ozgür A. Classification of beta-lactamases and penicillin binding proteins using ligand-centric network models. PLoS ONE. 2015;10:1-23.

28. Andrews J. Detection of extended-spectrum beta-lactamases (ESBLs) in $E$. coli and Klebsiella species. BSAC. 2012. http://www.bsac.org.uk.

29. Lin J, Nishino K, Roberts MC, Tolmasky M, Aminov R, Zhang L. Mechanisms of antibiotic resistance. Front Microbiol. 2015;6:1-3.

30. Flemming HC, Wingender J, Szewzyk U, Steinberg P, Rice SA, Kjelleberg S. Biofilms: an emergent form of bacterial life. Nat Rev Microbiol. 2016;14:563-75.

31. Olsen I. Biofilm-specific antibiotic tolerance and resistance. Eur J Clin Microbiol Infect Dis. 2015:34:877-86.
32. Jefferson KK. What drives bacteria to produce a biofilm? FEMS Microbiol Lett. 2004;236:163-73.

33. Jamal M, Ahmad W, Andleeb S, Jalil F, Imran M, Nawaz MA, Kamil MA. Bacterial biofilm and associated infections. J Chin Med Assoc. 2017:81(1):7-11.

34. Cergole-Novella MC, Pignatari ACC, Guth BEC. Adhesion, biofilm and genotypic characteristics of antimicrobial resistant Escherichia coli isolates. Braz J Microbiol. 2015;46(1):167-71.

35. Schembri MA, Kjaergaard K, Klemm P. Global gene expression in Escherichia coli biofilms. Mol Microbiol. 2003:48(1):253-67.

36. Tan CK, Ulett KB, Steele M, Benjamin WH, Ulett GC. Prognostic value of semi-quantitative bacteruria counts in the diagnosis of group $B$ Streptococcus urinary tract infection: a 4-year retrospective study in adult patients. BMC Infect Dis. 2012;12(1):273.

\section{Publisher's Note}

Springer Nature remains neutral with regard to jurisdictional claims in published maps and institutional affiliations.
Ready to submit your research? Choose BMC and benefit from:

- fast, convenient online submission

- thorough peer review by experienced researchers in your field

- rapid publication on acceptance

- support for research data, including large and complex data types

- gold Open Access which fosters wider collaboration and increased citations

- maximum visibility for your research: over 100M website views per year

At BMC, research is always in progress.

Learn more biomedcentral.com/submissions 